\title{
THE PARADOX OF ADDITION AND ITS DISSOLUTION
}

MARIO BUNGE

McGill University

Some systems of modal logic, and some of deontic logic, contain a rule of addition similar to the rule of addition of the propositional calculus. In the case of imperatives, that rule reads: "The obligation of $p$ entails the obligation of $p$ or the obligation of $q$ ". This rule gives rise to a paradox that may be called the paradox of addition, which can be illustra. ted thus: the command "Close the door" entails the imperatives "Close the door or kiss me", "Close the door or jump in the lake", and so on and so forth. Hence the recipient of the order might be said to obey it if, instead of closing the door, he kisses the author of the utterance, or jumps in the lake or, indeed, if he does (or fails to do) anything whatsoever.

This paradox is not peculiar to modalities or imperatives: it raises its ugly head in truth functional logic as well. Indeed, the principle of addition for propositions reads: " $p$ entails $p$ or $q$, where $q$ is an arbitrary statement". In particular, $q$ could be the negate of $p$. Or $q$ could be a proposition belonging to a totally disjoint universe of discourse. And this could lead to proving or disproving anything whatever. Thus the Pythagorean theorem - call it $p$ - entails the alternative "p or arctic winters are lovely", which is equivalent to "If not-p, then arctic winters are lovely". Since as a matter of fact artic winters fail to be lovely, by modus tollens the Pythagorean theorem is proved by a bit of meteorology, which is ludicrous.

This nonsense is not a matter of syntax: the principle of addition is valid - though with a qualification to be made 
below. Nor is it a question of suitably interpreting the disjunction occurring in it. Nor, finally, is it a question of reinterpreting entailment. What is at stake is the extralogical ingredient of the statements in question, i.e. the nonlogical predicates occurring in $p$ and $q$. Unless these are homogenenized - hence unless the universe of discourse is closed up - paradoxes are bound to occur in the applications of the principle of addition. No absurdities will occur if $q$ is semantically akin to $p$.

More precisely, nonlogical theories and systems of norms should exhibit not only formal unity (connectedness and consistency) but also semantical unity. I have examined elsewhere $^{1}$ four factors of semantical unity, which I have called unity of reference, semantical homogeneity of the predicates, semantical closure, and conceptual connectedness. Referential unity: the formulas of the system must concern a given reference class that must not be altered in the course of argument. Thus if the postulates (or the basic norms) concern only persons, then all the logical consequences of those principles should refer exclusively to persons as well. Semantical homogeneity: the predicates must all belong to the same semantical family - e.g. legal but not legal mixed with predicates typical of high energy physics. Semantical closure: the predicates of the system must not be augmented in the course of a deduction: they must constitute a closed set. (This condition of semantic closure suffices to avoid misapplications of the principle of addition.) Conceptual connectedness: the concepts of the system must be distributed among the various basic principles of the system, so that no isolated subsystem remains.

In the light of the preceding remarks, the principle of addition for propositions should be reformulated as follows: "From $p$ infer $p$ or $q$, provided all the extralogical predicates occurring in q apply to the individual(s) referred to by p". Similarly in modal logic and in deontic logic: "The necessity (obligation) of $p$ entails the necessity (obligation) of $p$ or 
the necessity (obligation) of $q$, provided all the extralogical predicates occurring in $q$ apply to the individual(s) referred to by p". In other words: when making inferences do not mix up disjoint universes of discourse. (This caution is similar to the one placed on Craig's interpolation theorems.) If this restriction is not observed, nonsense may crop up. Just as Ex falso sequitur quodlibet, so Ex mixto sequitur fere quodlibet: out of a mixture almost anything follows. If different domains of individuals must be brought together, then let us mix them at the level of principles, e.g. by requiring that certain functions be defined on the cartesian product of the corresponding sets. Failure to do so is a permanent source of confusion in the interpretations of quan. tum theories. ${ }^{2}$

The four components of semantical unity we listed above are automatically secured in axiomatic theories. Here the universe of discourse and the predicates are listed in advance and there is no possibility of smuggling foreigners into either set at a later stage. Whence the safety of inferences conducted within axiom systems. If only for this reason it would be desirable to conduct every delicate ethical and legal reasoning within similarly constructed systems of primary and derivative norms. ${ }^{8}$

In conclusion, (a) the paradox of addition for necessities and obligations has a partner in extensional logic; (b) neither of these paradoxes occur normally, because of a tacit abeyance by the principle of semantical unity; (c) they are systematically avoided by working in axiomatic theories or in principled bodies of norms.

I am grateful to Ilmar Tammelo (Sydney) for a stimulating discussion and for a critical reading of a draft of this note.

1 M. Bunge, Scientific Research, 2 vols. (Berlin Heidelberg-New York: Springer-Verlag, 1967), I, pp. 391-396.

2 M. Bunge, "What are physical theories about?", American Philosophical Quarterly Monograph No. 3, Studies in the Philosophy of Science (1969).

3 For a systematic analysis of the concept of a system of norms, see C E. Alchourrón and E. Bulygin, Normative Sistems (Wien-New York: SpringerVerlag, 1970). 
RESUMEN

Algunos sistemas de lógica modal y de lógica deóntica contienen una regla de adición semejante a la del cálculo proposicional. En el caso de los imperativos dicha regla se expresaría de la siguiente manera: "La obligación de $p$ implica la obligación de $p$ o la obligación de $q "$. Esta regla da lugar a una paradoja que puede llamarse la paradoja de la adición. Esta paradoja no es peculiar a las modalidades o a los imperativos; aparece también en la lógica extencional, en donde la regla de la adición se expresa así: "p implica $p$ o $q$ " donde $q$ es un enunciado arbitrariamente escogido. Esta regla podría servir para probar o refutar cualquier cosa.

Este sinsentido no es sólo una cuestión de sintaxis: el principio de adición es válido con una cualificación que se le hará más adelante. No se trata de reinterpretar la disyunción ni el condicional mismo. Lo que está en juego son los ingredientes extralógicos de los enunciados en cuestión, esto es, los predicados no-lógicos que aparezcan en $p$ y $q$. A menos que estos se hagan homogéneos y que por lo tanto el universo del discurso se cierre, las paradojas de la adición pueden aparecer.

Los sistemas y teorías no-lógicos deberían exhibir no sólo una unidad formal sino también una unidad semántica. He examinado en otro artículo cuatro factores de la unidad semántica: la unidad de referencia, la homogeneidad semántica de los predicados, la clausura semántica y la conexión conceptual.

El principio de la adición debería reformularse de la siguiente manera: "A partir de $p$ infiérase $p$ o $q$ siempre que los predicados extralógicos que aparezcan en $q$ se puedan aplicar a los individuos a los que se refiere $p$ ". De manera similar en la lógica modal y en la lógica deóntica: "La necesidad (obligaciós) de $p$ implica la necesidad (obligación) de $q$ siempre que los predicados extralógicos que aparezcan en $q$ puedan aplicarse a los individuos a los que se refiere $p$ ". De no observarse esta restricción pueden surgir sinsentidos.

Los cuatro factores de la unidad semántica antes mencionados es. tán automáticamente asegurados en teorias axiomáticas. Aquí el universo del discurso y los predicados están determinados de antemano y no hay ninguna posibilidad de introducir elementos ajenos en ninguno de los dos conjuntos en una etapa posterior. De aquí la seguridad de las inferencias practicadas dentro de sistemas axiomáticos. 
En conclusión, (a) la paradoja de la adición para necesidades y obligaciones encuentra su contraparte en la lógica extensional; (b) ninguna de estas paradojas ocurre normalmente, sólo ocurre en casos en que se suspende tácitamente el principio de la unidad semántica; (c) se evitan sistemáticamente al trabajar en teorías axiomáticas. 